\title{
Effect of heat inactivation for the detection of severe acute respiratory syndrome-corona virus-2 (SARS-CoV-2) with reverse transcription real time polymerase chain reaction (rRT-PCR): evidence from Ethiopian study
}

Belete Woldesemayat ${ }^{1 *} \mathbb{D}$, Gebremedihin Gebremicael ${ }^{1}$, Kidist Zealiyas ${ }^{1}$, Amelework Yilma ${ }^{1}$, Sisay Adane ${ }^{1}$, Mengistu Yimer ${ }^{1}$, Gadissa Gutema ${ }^{1}$, Altaye Feleke ${ }^{1}$ and Kassu Desta ${ }^{2}$

\begin{abstract}
Background: Coronavirus disease 2019 (COVID-19) has been a major public health importance and its specimen needs to be handled safely due to concerns of potential transmissibility to health care workers. Heat inactivation of the sample before nucleic acid isolation might permit safe testing processes. Hence, it is important to assess the effect of heat inactivation on SARS-CoV-2 RT-PCR detection in resource limited settings.

Methods: An experimental study was conducted at Ethiopian Public Health Institute (EPHI) from September 25 to October 15, 2020. A total of 188 Oro-pharyngeal swabs were collected from COVID-19 suspected cases, referred to EPHI for SARS COV-2 testing. One batch of the sample was inactivated at $56^{\circ} \mathrm{C}$ heat for $30 \mathrm{~min}$, and the other batch was stored at $4{ }^{\circ} \mathrm{C}$ for a similar period of time. RNA extraction and detection were done by DAAN Gene kit protocols. Abbott m2000 RT-PCR was used for amplification and detection. Data analysis was done by using SPSS version 23.0; Chi-square and Pearson correlation test for qualitative and semi-quantitative analysis were used. $p$-value $<0.05$ was considered as statistically significant.
\end{abstract}

Results: Out of 188 total samples, 119 (63.3\%) were positive and 69 (36.7\%) were negative in the non-inactivated group. While, 115 (61.2\%) of samples were positive and 73 (38.8) were negative in heat inactivated sample batch. Rate of positivity between groups did not have statistically significant difference $(p>0.05)$. The mean Cycle threshold $(C t)$ value difference between the two groups of ORF1a/b gene and $\mathrm{N}$ gene was $0.042(95 \% \mathrm{Cl}-0.247-0.331 ; \mathrm{t}=0.28$; $\mathrm{p}=0.774)$ and $0.38(95 \% \mathrm{Cl} 0.097-0.682 ; \mathrm{t}=2.638 ; \mathrm{p}=0.010)$ respectively.

Conclusion: Heat inactivation at $56^{\circ} \mathrm{C}$ for $30 \mathrm{~min}$ did not affect the qualitative rRT-PCR detection of SARS-CoV- 2 . However, the finding showed that there was statistically significant Ct value increment after heat inactivation compared to untreated samples. Therefore, false-negative results for high $\mathrm{Ct}$ value $(\mathrm{Ct}>35)$ samples were found to be the

*Correspondence: beleteweldesemeyat@gmail.com

${ }^{1}$ HIV/AIDS Disease Research Team, TB and HIV/AIDS Disease Research

Directorate, Ethiopian Public Health Institute, P.O. Box 1242, Addis Ababa,

Ethiopia

Full list of author information is available at the end of the article

(c) The Author(s) 2022. Open Access This article is licensed under a Creative Commons Attribution 4.0 International License, which permits use, sharing, adaptation, distribution and reproduction in any medium or format, as long as you give appropriate credit to the original author(s) and the source, provide a link to the Creative Commons licence, and indicate if changes were made. The images or other third party material in this article are included in the article's Creative Commons licence, unless indicated otherwise in a credit line to the material. If material is not included in the article's Creative Commons licence and your intended use is not permitted by statutory regulation or exceeds the permitted use, you will need to obtain permission directly from the copyright holder. To view a copy of this licence, visit http://creativecommons.org/licenses/by/4.0/. The Creative Commons Public Domain Dedication waiver (http://creativeco mmons.org/publicdomain/zero/1.0/) applies to the data made available in this article, unless otherwise stated in a credit line to the data. 
challenge of this protocol. Hence alternative inactivation methods should be investigated and further studies should be considered.

Keywords: COVID-19, Ct value, Heat inactivation, rRT-PCR, SARS-CoV-2

\section{Background}

Coronavirus diseases 2019 (COVID-19) was announced as a global pandemic on March 11, 2020, by World Health Organization (WHO) [1]. As of December $12 / 2021$, severe acute respiratory syndrome-2 (SARS CoV-2) infections have been confirmed in nearly 269 million people, and about 5.3 million deaths reported globally [2]. Laboratory testing for COVID-19 has a major importance to show a real scenario of the detected cases in this pandemic era. The testing method can be Nucleic Acid Amplification Test (NAAT) or Serological tests [3]. However, the new recommended point-of-care serological test was failed to be recommended by WHO to use in any setting, including in clinical decision-making rather than in research settings due to window time [4]. Therefore, detection of SARS-CoV-2 RNA with molecular methods (either PCR-based method or deep sequencing) is the gold standard method for the diagnosis of COVID-19. Reverse transcription real-time polymerase chain reaction (rRT-PCR) are using specific sequences of genes that encode the RNA dependent RNA polymerase (RdRP), nucleocapsid (N), envelope (E), and spike (S) proteins of the virus [5]. However, currently available diagnostic method of COVID-19 either PCR-based or deep sequencing have limitations in terms of reliability, accuracy, and accessibility of testing [6]. Because, these detection methods are dependent on the presence of viral genome in sufficient amounts that can be amplified [7]. In addition, in the process of the analytical procedure, there are a lot of challenges including sample collection, transportation, treatment, extraction procedure, amplification and detection [6]. Moreover, according to WHO biosafety guideline COVID-19 molecular testing by using clinical specimens should be performed at least in Biosafety Level 2 (BSL-2) laboratory [8]. Therefore, initial sample processing (before inactivation) of all specimens should be performed in a properly maintained and calibrated biosafety cabinet (BSC). In some condition, including in point of care testing, specimen handling and testing out of designated testing centers, conducting different field surveys settings and when performing automation extraction might be unable to use BSC's. Thus, specimen treatment (inactivation of SARS-CoV-2) prior to sample handling or extraction could be essential to protect health care workers from nosocomial transmission of COVID-19 [8-10].
Inactivation of SARS-CoV-2 can be done by different methods; like chemical inactivation using $0.5 \%$ of Povidone-Iodine oral antiseptic, and/or 70\% alcohol can be rapidly inactivate the virus within $30 \mathrm{~s}$ contact time [11]. Lysis buffers which are available in RNA extraction kit are also effective for SARS-CoV-2 inactivation without additional means [8]. However, some detergents using for sample treatment can inhibit PCR reactions. Some of cannot inactivate viruses properly without RNA degradation [6]. Different strain of the virus could be inactivated with related temperature range [12]. The famous method of SARS-CoV-2 inactivation at $56{ }^{\circ} \mathrm{C}$ for $30 \mathrm{~min}$ prior to extraction procedures was showed that leads to a clear drop of viral infectivity (>5 $\log 10$ reduction) $[10,13]$. The other SARS-CoV-2 inactivation at $60{ }^{\circ} \mathrm{C}$ for $60 \mathrm{~min}$, $92{ }^{\circ} \mathrm{C}$ for $15 \mathrm{~min}, 80{ }^{\circ} \mathrm{C}$ for $5 \mathrm{~min}$, and $100{ }^{\circ} \mathrm{C}$ for one minute also could be resulted significantly decrease the viral infectivity in a clinical specimen [13, 14]. However, sample treatment that use heat before molecular testing might destroy the viral RNA and can lead to false-negative results [15].

Since COVID-19 outbreak occurred in Ethiopia, laboratory testing is conducted with NAAT by using RT-PCR technique from Nasopharyngeal or Oro-pharyngeal specimens with automated or manual extraction and detection methods. In this pandemic time expansion of the testing capacity should be important steps that boost the prevention and control strategy of COVID19 throughout the country. However, resource limitations including level 2 biosafety cabinets are the major challenge. In addition to this, automated extraction and detection are conducted by using different type of instruments in the absence of biosafety cabinet. In this sense, viral inactivation is a mandatory process in order to protect health care workers from the nosocomial transmission of SARS-CoV-2. Currently, in our context, we are using heat at $56{ }^{\circ} \mathrm{C}$ for $30 \mathrm{~min}$ for viral inactivation. But some shreds of evidence showed that viral inactivation for RNA viruses, including SARS-CoV-2 lead to a false-negative result. Hence we have aimed to evaluate the effect of heat inactivation in the detection of SARSCoV-2 by using clinical samples in Ethiopian context and generate baseline information for further study on the use of inactivation method prior to nucleic acid extraction for COVID-19 testing that could be applicable in similar settings. 


\section{Methods}

This experimental study was conducted at EPHI, National HIV Reference laboratory from September 25 to October 15,2020 . A total of 188 Oro-pharyngeal swabs were collected from COVID-19 suspected cases and referred to EPHI for SARS COV-2 testing during the study period. Oro-pharyngeal sample was collected by trained sample collectors, with $3 \mathrm{ml}$ viral transport media (VTM) (Miraclean technology, Shenzhen, China).Specimens were transported to EPHI, HIV reference laboratory by triple packaging system and the tertiary containers were opened inside the biosafety cabinet level 2 (BSCL-2).

From each, Oro-pharyngeal (throat swab) sample, $500 \mu \mathrm{l}$ sample was aliquoted into two sterilized cryogenic tubes. Then, one batch of the sample was inactivated at $56{ }^{\circ} \mathrm{C}$ heat for $30 \mathrm{~min}$ in a water bath and the other batch of the sample was stored at $4{ }^{\circ} \mathrm{C}$ for a similar period of time. Both batches of the sample were tested with a lot of 20 samples and 2 controls (1 positive and1 negative), were included throughout the procedure (in extraction and detection) except the last batch of samples, which contained 8 samples and controls. During extraction and master mixing, every step was performed based on standard operating procedure (SOP), every batch of testing was treated similarly, except one group inactivated with heat and the other is not, to minimize factors that can affect the result. The RNA extraction was done by DAAN Gene spin column-based manual extraction kit, manufactured by DAAN Gene Co., Ltd of Sun Yat-sen University, Guangzhou China. In this method of nucleic acid isolation/purification $0.2 \mathrm{ml}$ of VTM throat swab sample was used for manual extraction. In short, $0.2 \mathrm{ml}$ of samples was mixed with $50 \mu \mathrm{l}$ of proteinase $\mathrm{K}$ and $200 \mu \mathrm{l}$ of lysis buffer. The lysed samples were heated for 10 min on a dry heat block at $72{ }^{\circ} \mathrm{C}$. Extracted nucleic acid was precipitated by using $250 \mu \mathrm{l}$ of absolute ethanol and after subsequent washing steps adds $50 \mu \mathrm{l}$ of elution buffer. Finally, approximately $50 \mu \mathrm{l}$ of eluate was collected with $1.5 \mathrm{ml}$ eppendrof tube. The amplification/detection method of this kit is based on one-step rRT-PCR technique. In this method, ORF1a/b and $\mathrm{N}$ genes are selected as the conserved region of DAAN technology for amplification and detection of target regions. Specific primers and fluorescent probes are designed ( $\mathrm{N}$ gene probe is labeled with Carboxyfluorescein (FAM) and ORF1a/b probe with VIC) for the detection of 2019 novel Coronavirus RNA in the specimens. The final master mix preparation was $5 \mu \mathrm{l}$ of eluate was added to $20 \mu \mathrm{l}$ of master mix for a volume of $25 \mu$ l. rRT-PCR was performed on the Abbott m2000 RT-PCR (open mode). Based on the manufacturer instruction cycling conditions was as follows: hold for 15 min's at $50^{\circ} \mathrm{C}$, hold for 15 min's at $95^{\circ} \mathrm{C}$, then 45 cycles of $94{ }^{\circ} \mathrm{C}$ for $15 \mathrm{~s}$, and $55^{\circ} \mathrm{C}$ for $45 \mathrm{~s}$.
The result interpretation was done based on the manufacturer recommendation, $\mathrm{Ct}$ value $>40$ and no amplification curve in the FAM and VIC channel, but amplification curve in $\mathrm{Cy} 5$ channel was considered as negative (no detectable SARS-CoV-2 RNA in the sample). On the other hand, if the sample had a clear amplification curve in the FAM and VIC channels and $\mathrm{Ct}$ value $\leq 40$, the sample was considered as positive for SARS-CoV-2 RNA. If the $\mathrm{Ct}$ value of $\leq 40$ and amplification curve was detected in a single channel of FAM or VIC, and there was no amplification curve in the other channel, the results were re-tested and the repeated result takes as the final result.

\section{Data processing and analysis}

The data entry and analysis was conducted using statistical software SPSS version 23.0. Descriptive statistics, chi-square and correlation analysis was done to compare different $\mathrm{Ct}$ values between groups. A paired T-test was used to measure the mean $\mathrm{Ct}$ value difference and to analyze the association between heat inactivated and non-heat inactivated samples $\mathrm{Ct}$ value using Pearson correlation coefficient analysis. The consistency analysis value $\mathrm{p}<0.05$ of the $\mathrm{Ct}$ values is considered statistically significant.

\section{Results}

In this study, a total of 188 COVID-19 suspected patients were enrolled and a throat swab sample was collected from September 25 to October 15/2020 referred to EPHI for SARS-CoV-2 testing. Of the total, 108 (57.4\%) participants were male and the rest $80(42.6 \%)$ were female. The mean age of the study participants was $32.2 \pm 13.1$ years.

The positive proportion of non-heat inactivated and heat inactivated samples in this study was 119 (63.3\%) and $115(61.2 \%)$ respectively (Table 1). Out of the total samples without heat-inactivated at $56{ }^{\circ} \mathrm{C}$ for $30 \mathrm{~min}$ (untreated group), 117 (62.2\%) and 119 (63.3\%) were positive for ORF1a/b gene and $\mathrm{N}$ gene respectively. While out of the samples with heat-inactivated at $56{ }^{\circ} \mathrm{C}$ for $30 \mathrm{~min}, 111$ (59\%) were ORF1a/b positive and $115(61.2 \%)$ were $\mathrm{N}$ gene positive. Out of the total $\mathrm{N}$ gene-positive,

Table 1 proportion of qualitative RT-PCR results of noninactivated and heat inactivated samples in COVID-19 testing, Ethiopia, 2020

\begin{tabular}{lll}
\hline Types of group & \multicolumn{2}{l}{ RT-PCR Qualitative result } \\
\cline { 2 - 3 } & Positive N (\%) & Negative N (\%) \\
\hline Non-heat inactivated sample group & $119(63.3)$ & $69(36.7)$ \\
Heat inactivated sample group & $115(61.2)$ & $73(38.8)$ \\
\hline
\end{tabular}


111 were ORF1a/b gene also positive. Only one sample $(0.5 \%)$ that treated with heat inactivation was turned to completely double target gene negative after re-tested; while five samples $(5 / 188=2.65 \%)$ were consistently single gene positive after re-tested. 69 (36.7\%) of untreated and $73(38.8 \%)$ of heat inactivated samples were negative for both target genes (ORF1a/b and $\mathrm{N}$ gene).

Of the total samples tested in both methods, 7 (3.7\%) discordant results were found (Table 2). Out of the discordant samples; 5 (71.4\%) Oro-pharyngeal specimen were double gene negative after the heat-inactivated procedure, but either double or single gene-positive in those treated without heat inactivation procedure. Interestingly, out of the discordant samples; 1 (14.3\%) sample was $\mathrm{N}$ gene-positive after heat-inactivation, but double gene negative in those treated without the heat-inactivated procedure. Those discordant samples having with single or double gene-positive $\mathrm{Ct}$ values were greater than 35 (Table 2). Based on the DAAN gene assay result interpretation after Chi-square McNemar test indicated that, the qualitative detection of SARS-CoV-2 (negativity or positivity) between heat-inactivated at $56{ }^{\circ} \mathrm{C}$ for $30 \mathrm{~min}$ and non-inactivated group result had no statistically significant difference $\left(\mathrm{x}^{2}=1.584 ; \mathrm{p}=0.208\right)$.
The effects of heat inactivation at $56{ }^{\circ} \mathrm{C}$ for $30 \mathrm{~min}$ on the SARS-CoV-2 RT-PCR Ct value were assessed. Out of 188 Oro-pharyngeal swab samples, the ORF1a/b gene average $\mathrm{Ct}$ value of the inactivation group and noninactivation group were 25.43 (95\% CI 24.369-26.521) and 25.39 (95\% CI $24.336-26.438)$ respectively. Out of the total sample, $32 / 188(17.02 \%)$ of samples had low ORF1a/b gene RNA copies, which had the $\mathrm{Ct}$ values were greater than 30 . While $22(11.7 \%) \mathrm{N}$ gene $\mathrm{Ct}$ values were greater than 30 . The mean non-inactivated ORF1a/b and $\mathrm{N}$ gene $\mathrm{Ct}$ values greater than 30 were 33.37 (95\% CI 32.43-34.32) and 32.52 (95\% CI 31.65-33.34) respectively. On the other hand, the inactivated ORF1a/b and $\mathrm{N}$ gene $\mathrm{Ct}$ values greater than 30 were 34.63 (95\% CI $33.46-35.85)$ and 33.52 (95\% CI 32.68-34.29) respectively (Table 3 ).

As shown in Table 3, there is no significant difference between the ORF1a/b Ct of inactivated and non-inactivated results. The mean difference between the two groups of Ct value was 0.042 (95\% CI - 0.247-0.331) and this difference was not statistically significant $(t=0.28$; $\mathrm{p}=0.774$ ). The Bland Altman comparison showed that, the lower and higher limit of agreement (LOA) between heat treated and non-treated samples were 7.378 and

Table 2 Discordant result list between inactivated and non-inactivated Oro-pharyngeal specimen in COVID-19 testing, Ethiopia, 2020

\begin{tabular}{llllll}
\hline Sample ID & \multicolumn{2}{l}{ Heat Inactivated result } & & \multicolumn{2}{l}{ Non-heat inactivated result } \\
& ORF1a/b gene (Ct value) & N gene (Ct value) & & ORF1a/b gene (Ct value) & N gene (Ct value) \\
\hline ES 020 & Negative & Negative & Positive (36.71) & Positive (36.22) \\
ES 073 & Negative & Negative & Positive (37.84) & Negative \\
ES 086 & Negative & Negative & Negative & Positive (36.62) \\
ES 150 & Negative & Negative & Positive (38.2) & Negative \\
ES 171 & Negative & Positive (36.61) & Positive (39.81) & Positive (36.93) \\
ES 067 & Negative & Positive (37.28) & Negative & Negative \\
ES 068 & Negative & Negative & Negative & Positive (36.38) \\
\hline
\end{tabular}

Table 3 Analysis of Ct value difference between heat inactivated and non-inactivated Oro-pharyngeal specimen in COVID-19 testing, Ethiopia, 2020

\begin{tabular}{|c|c|c|c|c|c|}
\hline \multirow[t]{2}{*}{ Variables } & \multirow[t]{2}{*}{ Mean $(95 \% \mathrm{Cl})$} & \multicolumn{3}{|l|}{ Paired T-test differences } & \multirow{2}{*}{$\begin{array}{l}\text { Non-parametric } \\
\text { Wilcoxon test } \\
\text { p-value }\end{array}$} \\
\hline & & Mean difference $(95 \% \mathrm{Cl})$ & T-test & p-value & \\
\hline Inactivated sample ORF1a/b gene Ct & $25.4397(24.369,26.521)$ & $0.042(-0.247,0.331)$ & 0.288 & 0.774 & 0.871 \\
\hline Non-inactivated sample ORF1a/b gene Ct & $25.3978(24.336,26.438)$ & & & & \\
\hline Inactivated sample $\mathrm{N}$ gene $\mathrm{Ct}$ & $24.1585(22.925,25.301)$ & $0.389(0.097,0.682)$ & 2.638 & 0.010 & 0.000 \\
\hline Non-inactivated sample N gene Ct & $23.7689(22.609,24.863)$ & & & & \\
\hline Inactivated sample ORF1a/b gene Ct> 30 & $34.6269(33.455,35.852)$ & $1.262(0.435,2.088$ & 3.114 & 0.004 & 0.001 \\
\hline Non-inactivated sample ORF1a/b gene Ct>30 & $33.3650(32.427,34.321)$ & & & & \\
\hline Inactivated sample $\mathrm{N}$ gene $\mathrm{Ct}>30$ & $33.5155(32.6796,34.293)$ & $1.00(0.439,1.561)$ & 3.709 & 0.001 & 0.000 \\
\hline Non-inactivated sample $\mathrm{N}$ gene $\mathrm{Ct}>30$ & $32.5155(31.646,33.3397)$ & & & & \\
\hline
\end{tabular}


- 7.294 respectively (Fig. 1A). On the other hand, the range of $\mathrm{N}$ gene $\mathrm{Ct}$ value in both inactivated and nontreated samples was $29.17(10.83-40.0)$ and 30 (10.040.0) respectively. The mean $\mathrm{Ct}$ value for $\mathrm{N}$ gene of the heat-treated group was 24.1585 (95\% CI 22.925-25.301) and the non-inactivated mean Ct value was 23.768 (95\% CI 22.609-24.863). The paired t-test analysis showed that the mean difference between both groups of $\mathrm{N}$ gene Ct was 0.38 (95\% CI 0.097-0.682). This difference indicated that, inactivated $\mathrm{N}$ gene $\mathrm{Ct}$ values were significantly higher compared to non-inactivated group $(t=2.638$; $\mathrm{p}=0.010$ ). The Bland Altman plot also revealed that, inconsistent $\mathrm{Ct}$ values were observed below and above the mean difference and the 95\% LOA was $3.479,-2.702$ (Fig. 1B). In addition, as indicated in paired T-test analysis, high $\mathrm{Ct}$ value $(>30)$ samples significantly affected with heat inactivation at $56{ }^{\circ} \mathrm{C}$ for $30 \mathrm{~min}$. The mean $\mathrm{Ct}$ value difference of ORF1a/b and $\mathrm{N}$ gene in both inactivated and non-inactivated groups were significantly different $(\mathrm{p}<0.05)$ (Table 3).

In this study the concordance between inactivated and non-inactivated sample results was compared and Pearson correlation analysis showed that, the ORF1a/b gene $\mathrm{Ct}$ values of inactivated sample and non-inactivated sample had excellent correlation ( $\mathrm{r}=0.978 ; \mathrm{p}<0.001)$; (Fig. 2). Similarly as Fig. 3 shows, the $\mathrm{N}$ gene $\mathrm{Ct}$ of inactivated and non-inactivated group had excellent correlation $(\mathrm{r}=0.969 ; 95 \%$ CI 0 0.934-0.991; $\mathrm{p}<0.001)$. According to Figs. 4 and 5, the ORF1a/b gene Ct value correlation between inactivated and non-inactivated groups had high positive correlation $(\mathrm{r}=0.749$; $95 \%$ CI $0.434-0.935$; $\mathrm{p}=0.000$ ). The $\mathrm{N}$ gene correlation between two groups had also strong positive correlation $(\mathrm{r}=0.824 ; 95 \% \mathrm{CI}$ $0.634-0.962 ; \mathrm{p}=0.000$ ).

\section{Discussion}

After COVID-19 declared as a global pandemic, the numbers of suspected cases were increased day today and that needs to maximize laboratory testing capacity by high throughput automated and point of care testing instruments for SARS-CoV-2 detection [6, 9]. For these types of platforms sample inactivation is an important procedure to protect health care workers from the exposure of SARS-CoV-2 infection [9]. However, some studies showed that sample inactivation by using heat can leads to RNA degradation and false-negative results [15, 16]. Therefore, this study was evaluated the effect of heat inactivation at $56{ }^{\circ} \mathrm{C}$ for $30 \mathrm{~min}$ for SARS-CoV-2 detection. In this study, seven samples (3.7\%) had discordant results between those heat-inactivated and without heatinactivated matched samples. Out of the total discordant samples, $71.4 \%$ of samples were double gene negative during the heat-inactivated procedure; but either double or single gene-positive in those without the heat-inactivated procedure. Those discordant samples having with single or double gene-positive were had more than 35 $\mathrm{Ct}$ value. A similar study performed in Beijing, China, showed that, the impact of heat inactivation on samples
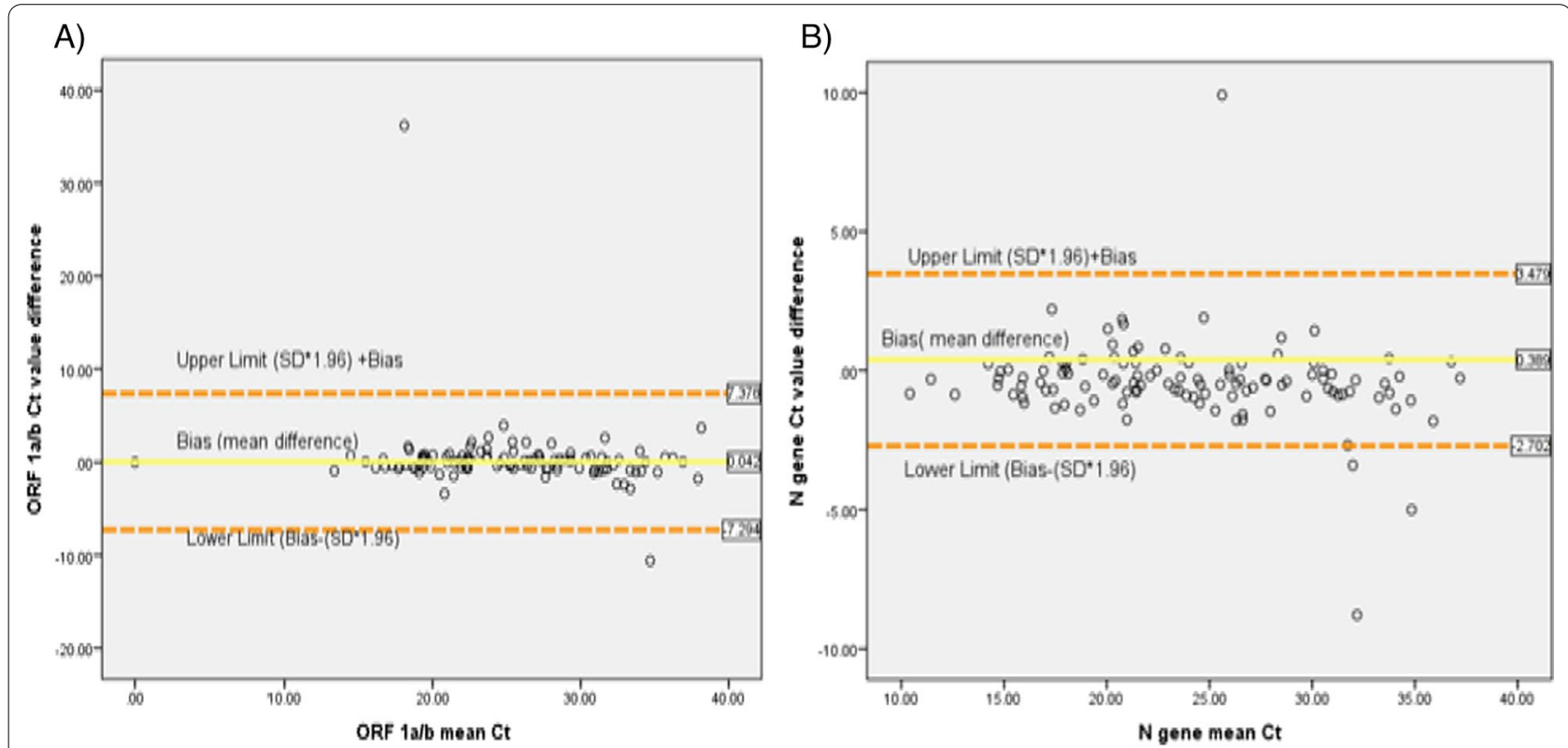

Fig. 1 Bland Altman plot of Ct value comparisons between heat-inactivated at $56^{\circ} \mathrm{C}$ for 30 min and non-inactivated group in COVID-19 testing, Ethiopia, 2020. A) ORF1 a/b gene Ct value comparisons between heat treated group and non-inactivated group. B) N gene Ct value comparisons between heat treated group and non-inactivated group 


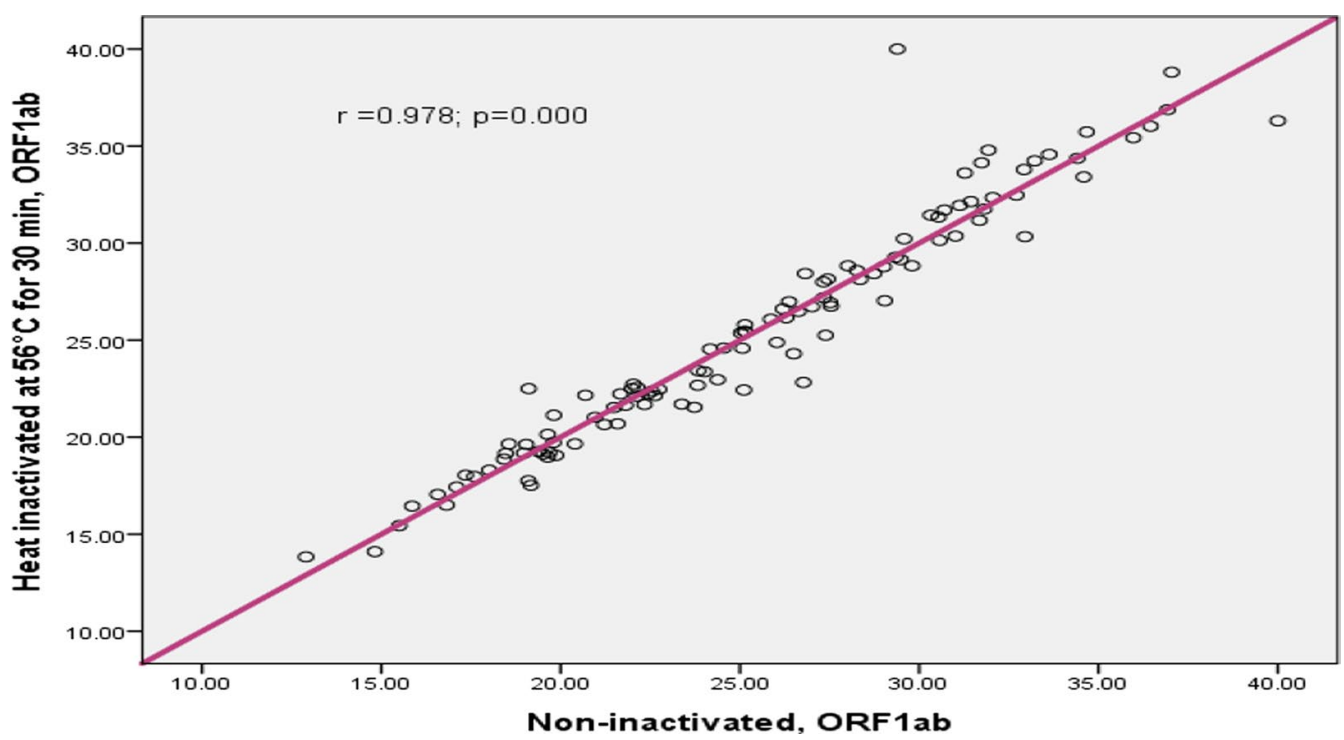

Fig. 2 Correlation of inactivated and non-inactivated ORF1a/b gene Ct for Oro-pharyngeal specimen in COVID-19 testing, Ethiopia, 2020

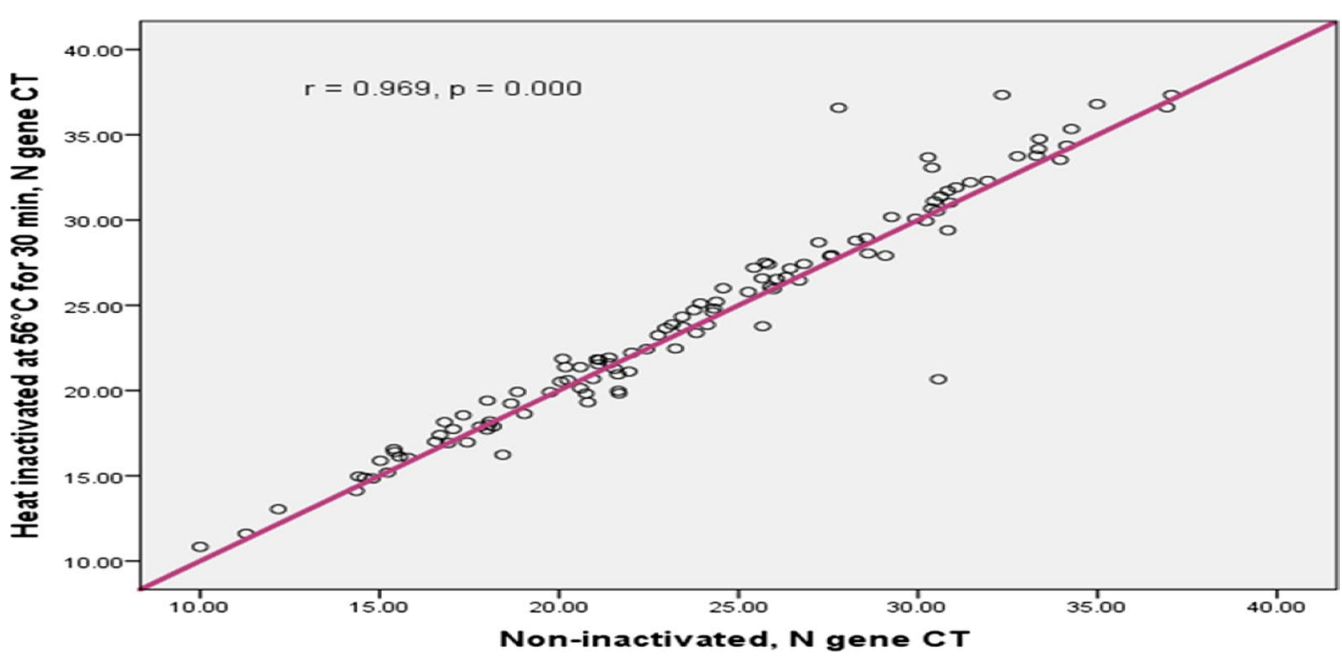

Fig. 3 Correlation of inactivated and non-inactivated N gene Ct for Oro-pharyngeal specimen in COVID-19 testing, Ethiopia, 2020

those had high Ct values (33.37-36.89) were high [16]. This indicates heat inactivation may have a negative impact on decreasing viral load of those samples having $\mathrm{Ct}$ values greater than 35. Early identification and detection, early prevention, and control are the currently available method to curbing the rapid spread of COVID19 infection. However, it may have a negative impact on these measures. Although heat inactivation makes safe for health care workers, false-negative individuals in the community may be transmitted to a wide range of people. On the other hand, the positivity and negativity of the original sample and the heat-inactivated sample result in this study was showed that had no statistically significant difference after a chi-square test $(p>0.05)$. Similar results were obtained from Renmin Hospital of Wuhan University, China [17], Zhujiang Hospital, China [18], and a study conducted in USA on sputum sample [9] has no significant difference between the non-inactivated and inactivated sample at $56^{\circ} \mathrm{C}$ for $30 \mathrm{~min}$ for the qualitative detection of SARS-CoV-2. On the contrary, a study conducted in Beijing, China [16] and Yongchuan District Center for Disease Control and Prevention of 


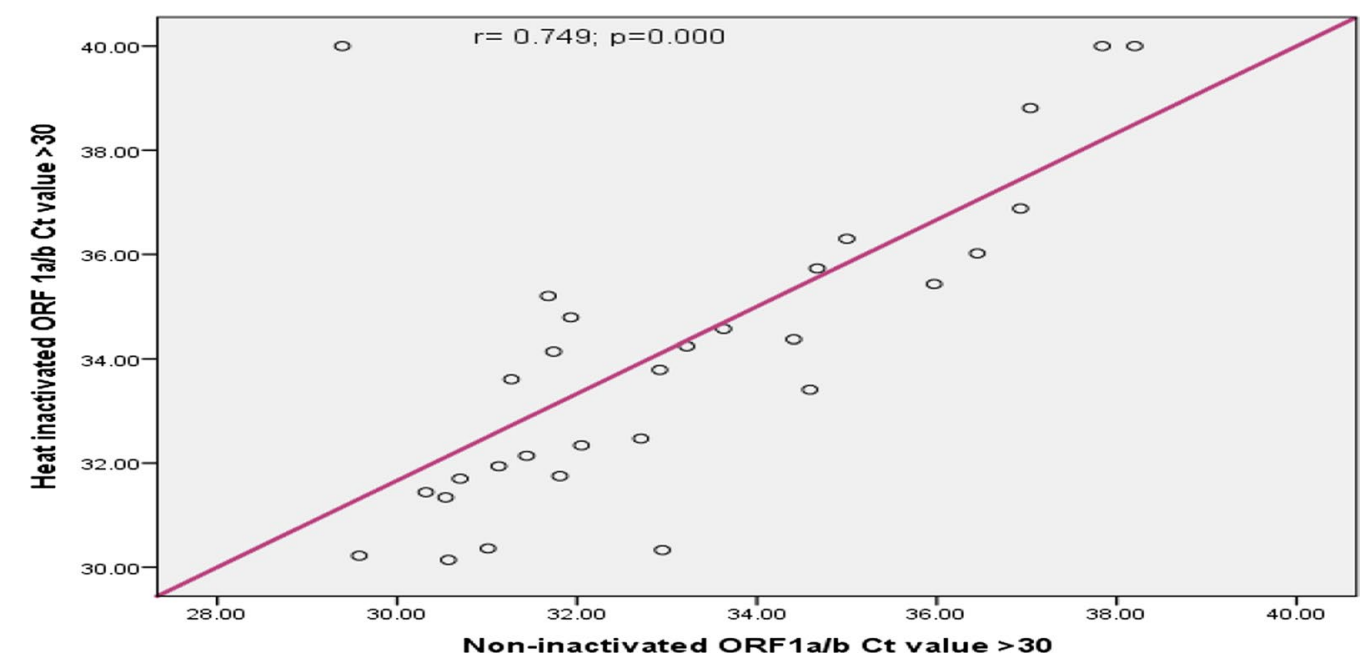

Fig. 4 Correlation of inactivated and non-inactivated ORF1a/b gene Ct value greater than 30 for Oro-pharyngeal specimen in COVID-19 testing, Ethiopia, 2020

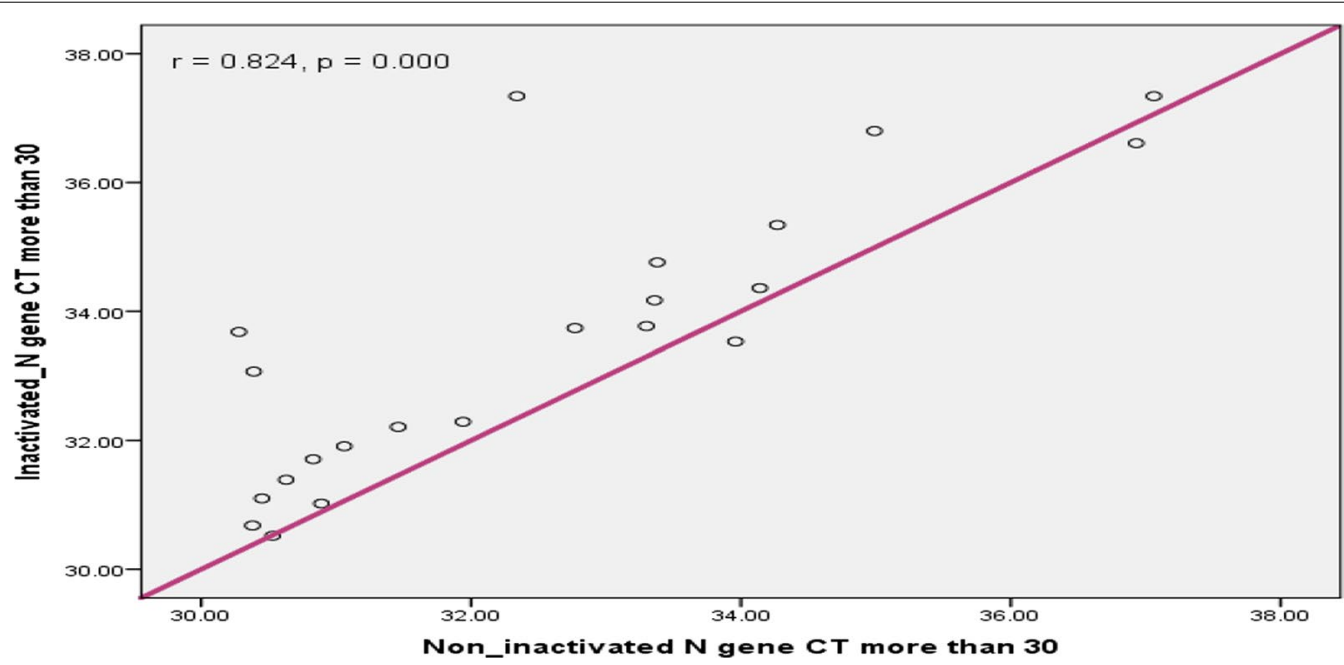

Fig. 5 Correlation of inactivated and non-inactivated N gene Ct value greater than 30 for Oro-pharyngeal specimen in COVID-19 testing, Ethiopia, 2020

Chongqing, China [19] were indicated that the qualitative detection of SARS-CoV-2 was significantly impacted with heat inactivation at $56^{\circ} \mathrm{C}$ for $30 \mathrm{~min}$. This difference might be due to variation in sample size between experiments, type of detection/extraction reagents, sample type and viral strain difference by itself. However, it is difficult to know the impact of this result on the transmission of SARS-CoV-2, as the virus is new, with lots of unknown characteristics and spreading as fast as a forest fire. In this study, the effect of heat inactivation at $56{ }^{\circ} \mathrm{C}$ for 30 min on the $\mathrm{Ct}$ value of matched samples was analyzed, and the average $\mathrm{Ct}$ value difference between non-inactivated and heat-inactivated at $56{ }^{\circ} \mathrm{C}$ for $30 \mathrm{~min}$ were 0.04 and 0.38 for ORF1a/b gene and $\mathrm{N}$ gene respectively. It means that after heat inactivation the ORF1a/b gene and $\mathrm{N}$ gene $\mathrm{Ct}$ was increased by 0.04 and 0.38 averagely on each sample respectively. Based on paired T-test analysis, the ORF1a/b gene Ct value increment after heat inactivation was not statistically significant $(t=0.28 ; p>0.05)$, whereas the $\mathrm{N}$ gene $\mathrm{Ct}$ values between inactivated and the non-inactivated group were statistically significant $(t=2.64 ; p=0.01)$. In addition to this, the mean $\mathrm{Ct}$ value difference of heat-treated and untreated group sample greater than $30 \mathrm{Ct}$ of ORF1a/b and $\mathrm{N}$ gene were 1.26 and 1.00 respectively. These average $\mathrm{Ct}$ value increment while heat inactivation was statistically significant in both $\mathrm{N}$ 
and ORF1a/b gene $(\mathrm{p}<0.05)$. Similar studies reported by Pan et al. [16] and Chen et al. [15] both were from China and indicated that heat inactivation prior to extraction can significantly reduce the number of RNAcopies (increased $\mathrm{Ct}$ values compared to the original sample). This may result in false-negative during heat inactivation procedure and favour viral transmission. However, the studies conducted in Charite University, Berlin, Germany [13], Renmin Hospital of Wuhan University, Huazhong China [17], Republic of South Korea [20] and Zhejiang University School of Medicine, China [21] revealed that $\mathrm{Ct}$ values of heat-inactivated at $56{ }^{\circ} \mathrm{C}$ for 30 min group and the non-inactivated group had no statistically significant difference. These difference might be due to sample size, type of sample or and type of strain difference circulating in the community which need additional investigations.

In this experimental study, the correlation between inactivated and non-inactivated samples was also examined. As a result, Pearson correlation analysis was performed and the analysis showed that, the ORF1a/b and $\mathrm{N}$ gene $\mathrm{Ct}$ values of inactivated sample and non-inactivated sample had excellent correlation $(\mathrm{r}=0.978 ; \mathrm{p}<0.001)$; and $(\mathrm{r}=0.969 ; \mathrm{p}<0.001)$ respectively (Figs. 2 and 3$)$. The result reported from the First People's Hospital of Zhaoqing, Zhao Qing City, China, the Ct value of ORF1a/b gene and $\mathrm{N}$ gene were perfectly correlated between inactivated at $56{ }^{\circ} \mathrm{C}$ for $30 \mathrm{~min}$ and non-inactivated samples [15].

Our study has some limitations; first, we have used only Oro-pharyngeal swabs, so we cannot conclude for another type of samples; like sputum, saliva, blood and stool samples. Second, we didn't perform SARS-CoV-2 viral quantification to show the exact viral copy difference between inactivated and non-inactivated sample results. And third, we did not perform viral infectivity analysis because of lack of infrastructure.

\section{Conclusion}

In conclusion, our result showed that heat inactivation at $56{ }^{\circ} \mathrm{C}$ for 30 min does not have statistically significant effect for the qualitative rRT-PCR detection (positivity or negativity rate of detection) of SARS-CoV-2 infection. However, this study showed that there was statistically significant $\mathrm{Ct}$ value increment after heat inactivation at $56{ }^{\circ} \mathrm{C}$ for $30 \mathrm{~min}$ compared to untreated samples. So, a false negative result in high Ct value (especially greater than 35 ) might be the challenge of this protocol. Finally for SARS-CoV-2 viral inactivation prior to sample handling or extraction other inactivation methods rather than heat inactivation and further studies should be considered. By replicating this study the real effect of heat inactivation on the detection of SARS-CoV-2 viral genomic materials could be known which will have an impact on the diagnosis and prognosis of COVID-19 patients specifically in resource-limited settings.

\section{Abbreviations}

BSC: Biological safety cabinet; BSCL2: Biosafety cabinet level 2; CDC: Center for disease control; COVID-19: Coronavirus disease 19; Ct: Cycle threshold; EPHI: Ethiopian Public Health Institute; IC: Internal control; NAAT: Nucleic acid amplification test; ORF1a/b: Open reading frame 1a/b; POC: Point of care; rRTPCR: Reverse transcriptase real time polymerase chain reaction; SARS CoV-2: Sever Acute Respiratory Syndrome Corona Virus-2; SOP: Standard operation procedure; VTM: Viral transport media; WHO: World Health Organization.

\section{Acknowledgements}

We would like to acknowledge Ethiopian Public Health Institute (EPHI) for material and reagent support. My appreciation also goes to all staffs of EPHI, HIV/AIDS disease research team for their cooperation on specimen handling and laboratory analysis.

\section{Authors' contributions}

BW: Conception of the study, writing the original draft, study design, data analysis and interpretation; GG1: study design, data analysis, critical review of the manuscript; KZ: writing the original draft, study design and critical review of the manuscript; AY: laboratory investigation and critical review of the manuscript; SA: laboratory investigation, data acquisition and study design; MY: laboratory investigation, data acquisition and study design; GG2: writing the original draft and study design; AF: study design; KD: Manuscript critical review and final approval of the version to be submitted. All authors read and approved the final manuscript.

\section{Funding}

Ethiopian public health institute was support the reagents and materials used for this study. However, the funding body had no role in data collection, study design, analysis, data interpretation and in writing the manuscript.

\section{Availability of data and materials}

All data generated or analysed during this study are included in this published article. The data that support the findings of this study are available from the corresponding author on reasonable request.

\section{Declarations}

\section{Ethics approval and consent to participate}

Ethical clearance was received from Ethiopian public health institute scientific ethical review committee with reference number EPHI-IRB-279-2020. Written informed consent was obtained from all participants prior to participation and we did not use any personal identifiers and all information's are kept confidential.

\section{Consent for publication}

Not applicable.

\section{Competing interests}

All authors declare that they have no conflict or competing interests.

\section{Author details}

${ }^{1}$ HIV/AIDS Disease Research Team, TB and HIV/AIDS Disease Research Directorate, Ethiopian Public Health Institute, P.O. Box 1242, Addis Ababa, Ethiopia. ${ }^{2}$ Department of Medical Laboratory Sciences, College of Health Sciences, Addis Ababa University, Addis Ababa, Ethiopia.

Received: 1 January 2021 Accepted: 9 February 2022

Published online: 21 February 2022 


\section{References}

1. ArunZanke A, Thenge RR, Adhao VS. COVID-19: a pandemic declare by world health organization. IP Int J Compr Adv Pharmacol. 2020;5(2):49-57.

2. World Health Organization (WHO). Coronavirus disease (COVID-19), weekly update.2021; available from; https://www.who.int/publicatio ns/m/item/weekly-epidemiological-update12-December-2021.

3. Esbin MN, Whitney ON, Chong S, Maurer A, Darzacq X, Tjian R. Overcoming the bottleneck to widespread testing: a rapid review of nucleic acid testing approaches for COVID-19 detection. RNA. 2020;26(7):771-83.

4. World Health Organization (WHO). Advice on the use of point-of-care immunodiagnostic tests for COVID-19. WHO. 2020; available from; https:// www.who.int/news-room/commentaries/detail/advice-on-the-use-ofpoint-of-care-immunodiagnostic-tests-for-covid-19.

5. Kumar R, Nagpal S, Kaushik S, Mendiratta S. COVID-19 diagnostic approaches: different roads to the same destination. Virus Dis. 2020;31(2):97-105. https://doi.org/10.1007/s13337-020-00599-7.

6. Feng W, Newbigging AM, Le C, Pang B, Peng H, Cao Y, et al. Molecular diagnosis of COVID-19: challenges and research needs. Anal Chem. 2020:92(15):10196-209.

7. Udugama B, Kadhiresan P, Kozlowski HN, Malekjahani A, Osborne M, Li VYC, et al. Diagnosing COVID-19: the disease and tools for detection. ACS Nano. 2020. https://doi.org/10.1021/acsnano.0c02624.

8. World Health Organization (WHO). Laboratory biosafety guidance related to the novel coronavirus (2019-nCoV). 2020 ;(World Health Organization; License: CC BY-NC-SA 3.0 IGO). Available from: https://www.who. int/docs/default-source/coronaviruse/laboratory-biosafety-novel-coron avirus-version-1-1.pdf?sfvrsn=912a9847_2.

9. Auerswald H, Yann S, Dul S, In S, Dussart P, Martin NJ, et al. Assessment of inactivation procedures for SARS-CoV-2. bioRxiv. 2020. https://doi.org/10. 1101/2020.05.28.120444.

10 Wang T, Lien C, Liu S, Selveraj P. Effective heat inactivation of SARS-CoV-2. medRxiv. 2020. https://doi.org/10.1101/2020.04.29.20085498v1.

11. Bidra AS, Pelletier JS, Westover JB, Frank S, Brown SM, Tessema B. Rapid in-vitro inactivation of severe acute respiratory syndrome coronavirus 2 (SARS-CoV-2) using povidone-iodine oral antiseptic rinse. J Prosthodont. 2020;29(6):529-33.

12. Abraham JP, Plourde BD, Cheng L. Using heat to kill SARS-CoV-2. Rev Med Virol. 2020;30(5):e2115.

13. Pastorino B, Touret $F$, Gilles $M$, De LX. Heat inactivation of different types of SARS-Cov-2 samples: what protocols for biosafety, molecular detection and serological diagnostics? Viruses. 2020;12(735):6-13.

14. Hessling M, Hoenes $K$, Lingenfelder C. Selection of parameters for thermal coronavirus inactivation - a data-based recommendation. GMS Hyg Infect Control. 2020; 15: ISSN 2196-5226.

15. Chen $H$, Wu R, Xing Y, Du Q, Xue Z, Xi Y, et al. Influence of different inactivation methods on severe acute respiratory syndrome coronavirus 2 RNA copy number. J Clin Microbiol. 2020; 58(8).

16. Pan $Y$, Long L, Zhang D, Yuan T, Cui S, Yang $P$, et al. Potential false-negative nucleic acid testing results for severe acute respiratory syndrome coronavirus 2 from thermal inactivation of samples with low viral loads. Clin Chem. 2020;66(6):794-801.

17. Wu Z, Zheng H, Gu J, Li F, Lv R, Deng Y, et al. Effects of different temperature and time durations of virus inactivation on results of real-time fluorescence PCR testing of COVID-19 viruses. Curr Med Sci. 2020;40(4):40-3.

18. Yanxia L, Cao Z, Chen M, Zhong Y, Luo Y, Shi G, et al. Effect of heat inactivation on real-time reverse transcription PCR of the SARS-COV-2 detection. J medRxiv. 2020. https://doi.org/10.1101/2020.05.19.20101469).

19. Zou J, Zhi S, Chen M, Su X, Kang L, Li C, et al. Heat inactivation decreases the qualitative real-time RT-PCR detection rates of clinical samples with high cycle threshold values in COVID-19. Diagn Microbiol Infect Dis. 2020:98(1):115109.

20. Kim Y-II, Casel MAB, Kim SM, Kim SG, Park SJ, Kim EH, et al. Development of severe acute respiratory syndrome coronavirus 2 (SARS-CoV-2) thermal inactivation method with preservation of diagnostic sensitivity. J Microbiol. 2020;58(10):886-91.

21. Xiuzhi D, Wang Xuchu YP. The effect of virus inactivation treatment on the weak positive results of the 2019 new coronavirus nucleic acid test. Chin J Insp Med. 2020;43(4):358-63.

\section{Publisher's Note}

Springer Nature remains neutral with regard to jurisdictional claims in published maps and institutional affiliations.
Ready to submit your research? Choose BMC and benefit from:

- fast, convenient online submission

- thorough peer review by experienced researchers in your field

- rapid publication on acceptance

- support for research data, including large and complex data types

- gold Open Access which fosters wider collaboration and increased citations

- maximum visibility for your research: over $100 \mathrm{M}$ website views per year

At BMC, research is always in progress.

Learn more biomedcentral.com/submissions 